\title{
Social Networking and Transnational Capitalism
}

\author{
David Kreps
}

d.g.kreps@salford.ac.uk, Organisations and Society Research Centre, Salford Business School, University of Salford, Salford, UK

\begin{abstract}
Social Networking Sites (SNS) have become a key component of users' experience of the internet. Whilst much has been made of the social dynamics of online SNS, the influence of the structures and operations of these sites - and the business models behind them - on users is rarely accounted for. This paper argues that behind the social behaviours supported by SNS, there is a growing shift towards viewing online communities as commodities, and SNS as an extension of mainstream capitalist ideologies fostered by existing patterns of commercialization and consumption. Using the works of Gramsci, Gill and Hardt \& Negri to provide a critical grounding, this paper explores the popular SNS site 'Facebook' and suggests that SNS may feel to the users to be free, social, personal, but in fact SNS are business as usual.
\end{abstract}

Keywords: Social networking, virtual communities, culture, politics, transnational capitalism

Social Networking Sites (SNS) - especially Facebook - continue to grow, yet the balance between the technological features of such sites which support social networking and those which facilitate online advertising remains precarious, and frequently makes national and international news. Whilst much has been written about the implications of social networks themselves, there has been little research into the nature and activities of those who develop and maintain the platforms upon which these networks rest. In particular, the venture capital which often seeds the growth of these sites is often treated as an anonymous and unremarkable part of the process.

This paper seeks to interrogate these aspects of SNS using cultural concepts originally developed by Antonio Gramsci, recently furthered by post-Gramscians such as Stephen Gill, and set into a new global context by the ground-breaking work of Hardt and Negri. Gramsci's cultural reworking of Marxist understandings of the nature of society, and particularly of capitalist societies, has given us the notion of hegemony. In the reading of Facebook offered in this paper, this author will further be positing a poststructuralist view of both the Gramscian and post-Gramscian analysis, influenced by such authors as Hardt \& Negri, and their reformulation of Foucauldian ideas in a political mien.

The first section of the paper introduces Facebook, the most popular social networking site, with a very brief overview of some of the literature about it and about social networking in general. This is followed by a section introducing the work of Antonio Gramsci, Stephen Gill, and Hardt \& Negri, connecting Gramsci's notion of hegemony through more recent analysis of transnational historical blocs into a more poststructuralist notion of the contemporary distributed Empire of transnational capitalism. The next section then points out the connections, making it clear that the world of social networking, far from being the free, new, different and virtual world uncritical analyses persist in imagining it to be, merely reproduces offline political and social realities online. In the final discussion and conclusion, some thoughts as to what this analysis might teach us about the future development of SNS are shared.

\section{Facebook}

Whilst there has been a fair amount of scholarship concerning SNS, much of it has focused on the interactions and networking of such sites, and much of the criticism upon the meaning of friendship there: for example, does competitive 'friending' turn these so-called friends into mere cyberacquaintances? Such 'friendliness' is no substitute for genuine friendship, according to Professor Ray Pahl, co-author of Rethinking Friendship (Spencer \& Pahl, 2006), and only leaves us feeling dissatisfied. In his opinion, Facebook is a form of immaturity, "It's not a real social network," he 
says, "it mimics the playground insecurities of primary school kids piling up best friends to find their social niche. When people grow up and settle down, they realise that real friendship isn't about turning on the computer - it requires real effort and taking the rough with the smooth" ("Facebook Scares Me," 2007). Sherry Turkle, in her recent book, "Alone Together," bemoans the increasing isolation use of SNS on mobile devices brings to individuals even when they are sitting in groups with their friends. She suggests that such use of Facebook is often the source and locus of presentation anxieties, and that many of the people in one's network are not "friends". They have been "friended", which is not the same thing (Turkle, 2010, p. 182).

Neither of the above studies seeks to analyse the phenomenon critically with respect to their relationship to contemporary capitalism. Indeed, the predominant form of social networking sites analysis found both in the computing and information systems literature (e.g. Kirchoff, StanoevskaSlabeva, Nicolai, \& Fleck, 2008; Wareham, Busquets, \& Austin, 2009; Chong \& Xie, 2011), and (if, perhaps, to a lesser extent) the media and communications literature (e.g. boyd, 2006; boyd \& Ellison, 2007; Song, 2010), is positivistic or at least politically uncritical. This paper aligns itself with those attempts at a more critical analysis of social networking sites and computer culture in general (Scholz, 2008; Fuchs, 2010a; 2010b; 2010c; 2011; Turner, 2006; Dean, 2009; Robins \& Webster, $1999)$ and argues that more are needed.

Indeed as Fuchs (2010b; 2010c) points out in his recent papers, the literature on social networking seems to focus on almost anything but a critical political analysis, drawing in a range of shallower concerns from "appearance and attractiveness" (Tom Tong et al., 2008; Walther et al., 2008) to "the rise of marketing relationships on SNS as a challenge for public relations" (Fuchs, 2010c, p. 173 referring to Meadow-Klues).

Facebook - the most successful SNS - was originally built for Harvard college students, in February 2004, by Harvard student Mark Zuckerberg and his 'friends', and grew during that year to include Stanford, Columbia and Yale (Malone, 2010). By May 2005 it had grown to support more than 800 college networks, was expanding into high-school networks, and then went international in October. In May 2006 it 'grew up,' adding to its existing six million-plus user-base non-student networks based around the workplace at first college staff, but soon businesses, corporations, and institutions. By the end of 2006, it had twelve million users (Malone, 2010). The summer of 2007, however, was the pivotal moment for Facebook as an SNS. In April there were twenty million users; in May they launched Facebook Platform, an Application Program Interface, or API, that allowed external developers to create and offer applications within Facebook, and by late summer 2008 the site boasted 100 million users (Malone, 2010). At the time of writing, in autumn 2011, it boasts over 700million users; it is arguable, of course, whether all are 'active users' (Malone, 2010). Nonetheless, in September 2011 half a billion people logged onto Facebook in one 24 hour period (Svetlik, 2011). The networking and socialization supported by Facebook is in many respects a hybrid, replicating 'real-world' social interactions alongside facilitating the formation of new contacts based on interest rather than physical proximity. The complex webs of social ties this generates argues against claims regarding the 'immaturity' of social networking friendships, but lends support to Turkle's assertion that some of these ties are the source of trouble for one's entire experience of the site.

Like many other SNS, Facebook has grown from being a focused community built around a narrow, fixed commonality - in Facebook's case, studenthood in the United States - into an international community where you can find almost anyone who might ever join an SNS and many for whom Facebook is their very first experience of online social networking. Users' personal profiles change constantly with the news of the activities of all of their linked friends, and messages from the pages of groups and commercial interests they have 'liked'. It is a virtual place of constant change, and perhaps this (at least appearance of) busy-ness is as much a part of its appeal as its ubiquity. But Facebook's extensive and popular but 'walled garden' approach to massive social networks (no search engine can see inside Facebook) clearly demonstrates a movement towards the commodification of virtual communities. 


\section{Gramsci, Hegemony, and the New World Order of Empire}

Commodification, consumerism, and the power of rich elites are the field of enquiry of cultural and political theorists. One such theorist whose writings have had a profound affect on our understanding of power in society is the early 20th century Italian thinker, Antonio Gramsci, who "recognised that social power is not a simple matter of domination on the one hand and subordination or resistance on the other" (Jones, 2006). Gramsci thus re-evaluated traditional Marxist understandings of modern capitalist societies by arguing that rather than being determined by underlying economic necessities, culture and politics formed a web of relations with the economy in which there is a continual shift of emphasis and influence. For this process he coined the term hegemony. In his Prison Notebooks Gramsci defines social hegemony as "The 'spontaneous' consent given by the great masses of the population to the general direction imposed on social life by the dominant fundamental group; this consent is 'historically' caused by the prestige (and consequent confidence) which the dominant group enjoys because of its position and function in the world of production" (Gramsci, 2007, p. 12). Importantly, as Jones points out in his study of Gramsci's work, "the maintenance of that consent is dependent upon an incessant repositioning of the relationship between rulers and ruled" (Jones, 2006, p. 3). Insidiously, a dominant bloc, in order to maintain its dominance, must be able to "reach into the minds and lives of its subordinates, exercising its power as what appears to be a free expression of their own interests and desires" (Jones, 2006, p. 4). In Gramsci's own words: "the fact of hegemony presupposes that account be taken of the interests and the tendencies of the groups over which hegemony is to be exercised, and that a certain compromise equilibrium should be formed - in other words, that the leading group should make sacrifices of an economic-corporate kind" (Gramsci, 2007, p. 161).

This aspect of unwitting collusion on the part of the ruled with the strategies and tactics of their rulers is perhaps the best known feature of Gramsci's concept of hegemony. That those strategies and tactics must constantly adapt to the shifting needs of the ruled is perhaps less appreciated. Dick Hebdige's work on subcultural groups perhaps expresses this dynamic best. A simple example of this approach is that of Punk. In the late 1970s, the wearing of safety pins in one's ear and of torn fabrics loosely arranged as clothing was a statement of rebellion, of rejection of fashion $\square$ similar to Dada earlier in the century (Hebdige, 1979). By the early 1980s, however, this 'look' had become a fashion in itself. What was revolutionary had been absorbed, packaged, and sold back to the revolutionaries. Lifestyles becoming available in the shops, in this way, brings consumerism into sharp relief. Everything is allowed, so long as it can be absorbed into the dominant socioeconomic model (i.e. if it can contribute to the market). Thus the pluralistic nature of the modern consumerist society arises.

This dominance of the modern market economy has been analysed by neo-Gramscian Stephen Gill, Professor of Political Science at Canada's York University. Gill's work on the New World Order created after $1945 \downarrow$ of which the world after 1991 he describes as but the third phase $\downarrow$ outlines the dominance of the market, of transnational capital, the G7 (and more recently G8 and G20) and the central role of US power in supporting and spearheading this dominance. The world after the Second World War, with its Marshall Plan, its NATO, and its emerging EEC, involved what Gill terms (using Gramscian language) an 'international historical bloc' built on a pax Americana (Gill, 2003, p. 58). Gramsci's post-Marxian analysis conceives the (economic) structures and (politi$\mathrm{cal} /$ ideological) superstructures of society as together forming an 'historical bloc' - "That is to say the complex, contradictory and discordant ensemble of the superstructures is the reflection of the ensemble of the social relations of production" (Gramsci, 2007, p. 366). In the aftermath of the terrible worldwide conflict of WW2, the American New Deal state became the model for the whole Western world, albeit somewhat modified by the changes required by wartime mobilisation and the 'military-industrial complex' this had spawned. Roosevelt's New Deal of the 1930s $\downarrow$ although it went further, at the time, and was later substantially cut back $\downarrow$ nonetheless represented a significant shift in political and domestic policy in the U.S., with its most lasting changes being an increased government control over the economy and money supply; intervention to control prices and agricultural production; the beginning of the federal welfare state, and the rise of trade union 
organizations. The Second World War tightened the relationship between government and economy through mandatory 'mobilisation' of industrial units and workforce for the production of arms. This mobilisation was not 'stood down' in 1945, as the Second World War became the Cold War, but evolved into what has since been termed the military-industrial complex $\downarrow$ the combination of a nation's armed forces, its suppliers of weapons systems, supplies and services, and its civil government. This military-industrial complex, moreover, through European and transatlantic treaties, special relationships and political settlements under American leadership, soon established what Gill terms an international military-industrial-complex, in which many countries' armed forces, weapons manufacturers, and government agencies are knitted together in co-dependent alliances. This international military-industrial complex, moreover, underpins an international, and American led economic model, an Internationalised New Deal, termed by Gill an international historical bloc (Gill, 2003, p. 58).

Despite Bush Senior's talk of a New World Order in 1991, Gill argues that the hegemony of American capitalism became a supremacy after the first Gulf War, with the collapse of the Soviet bloc and its absorption into the Western economy. Russia's recent attempts to re-establish its own sphere of influence have thrown this into sharp relief. This third phase New World Order was also a result of the gradual evolution, through the 1970s and 80 s, of a more integrated global political economy in which organised labour had become increasingly marginalised, and capitalist elites with significant investment in many different nations had emerged. Such elites include those in "key positions in transnational companies, banks, universities, think tanks, media companies, governments and international organisations such as the IMF, World Bank and OECD," linked by the discourse of neo-liberal globalisation (Gill, 2003, p.169). Thus the 1st and 2nd phase international historical bloc became transformed into an "American-centred and -led transnational historical bloc" (Gill, 2003, p. 59) at whose "apex are elements in the leading states in the G7 and capital linked to advanced sectors in international investment, production and finance" (Gill, 2003, p. 59) $\downarrow$ increasingly American firms $\downarrow$ whose activities "seek to make transnational capital a class 'for itself"' (Gill, 2003, p. 169).

It is important to recall, in the midst of Gill's rather bleak picture, that it is axiomatic in the analysis Gramsci provides that any "dominant group is coordinated concretely with the general interests of the subordinate groups, and the life of the State is conceived of as a continuous process of formation and superseding of unstable equilbria (on the juridical plane) between the interests of the fundamental group and those of the subordinate groups - equilbria in which the interests of the dominant group prevail, but only up to a certain point, i.e. stopping short of a narrowly corporate economic interest" (Gramsci, 2007, p. 182). In other words, any "ruling coalition will have to take on at least some of the values of those it attempts to lead, thereby reshaping its own ideals and imperatives" (Jones, 2006, p. 4). The exercise of power by a dominant bloc becomes a continuous and interpenetrative process, in which society becomes saturated with the meticulous negotiations between the desires of the dominant and the needs of the subjugated. Power becomes "something that is actively lived by the oppressed as a form of common sense" (Jones, 2006, p. 4). Power as understood through the concept of hegemony becomes exceedingly difficult to pin down, since it is always "in the process of becoming" (Jones, 2006, p. 5).

Gramsci's work is today situated within the literature of cultural criticism alongside other writers such as Loius Althusser (1970), and Michel Foucault (1994), both of whom have their criticisms of Gramsci's approach, and present their own alternatives. This is not the place for a wider discussion of these issues, save to present the caveat, in using the notion of cultural hegemony, that there are foundational assumptions about the nature of capitalist societies, divisions in society related to the concept of class, and a particular understanding of the nature and expression of power inherent in Gramsci's work that are not shared by other cultural theorists in the field. Foucault in particular refused to see power as something exercised by a dominant over a subservient class, insisting that power is derived from discourses - accepted ways of thinking, writing, and speaking $\downarrow$ and practices that amount to power. 
Hardt and Negri's vision of the world order, Empire (2000) (despite earlier strongly Marxian work, Negri, 1992; Hardt \& Negri, 1994) by contrast with Gill's analysis of a US led hegemony, takes, in many respects, a more poststructuralist, Foucauldian stance, declaring that the apparent "decline in sovereignty of nation-states [...] does not mean that sovereignty as such has declined [...] sovereignty has taken a new form, composed of a series of national and supranational organisms united under a single logic of rule" (Hardt \& Negri, 2000, p. xi-xii). They call this new global form of sovereignty, 'Empire', which is to be understood very differently from Imperialism. The earlier 'imperialist' form was centred, while the current 'Empire' is decentred. The earlier focused upon the boundaries of the nation state, making those within superior to those without, controlling the flow of goods and people across those boundaries to maintain that relation. The current form focuses upon boundaryless flow of goods and people and is thus "a decentred and deterritorialising apparatus of rule that progressively incorporates the entire global realm within its open, expanding frontiers" (Hardt \& Negri, 2000, p. xii). Empire is thus more a Foucauldian discursive formation than an old European imperialist power. "The United States does not", Hardt \& Negri assert, "and indeed no nation-state can today, form the centre of an imperialist project. Imperialism is over. No nation will be world leader in the way modern European nations were" (2000, p. xiv). This is arguably truer today than when it was written in 2000, with the rise of the BRIC countries (Brazil, India and China) and the relative decline in US power. Indeed it could be argued that the global financial crash of 2008 has created a fourth phase New World Order, in Gill's terms - a furthering in the development of Hardt \& Negri's Empire - a much more multipolar world.

But Hardt and Negri's analysis chimes nonetheless in places with the concept of hegemony, in that as Passavant notes in his commentary, "there is a consistent juridical logic that the actions of the police in Seattle share with the police in Genoa, and this is the logic of the imperial imperatives of Empire" (Passavant, 2002, p. 3). We have seen, indeed, that not only police forces, but parliaments will support the needs of the global financial system over those of their own people - as in Greece in 2011. It is clear that, albeit perhaps as a less obvious, more theoretical rulership than Gramsci may have envisaged, "the rule of Empire operates on all registers of the social order extending down to the depths of the social world" (Hardt \& Negri, 2000, p. xv). Again invoking a more Foucauldian understanding, it "not only regulates human interactions but also seeks directly to rule over human nature. The object of its rule is social life in its entirety, and thus Empire presents the paradigmatic form of biopower" (Hardt \& Negri, 2000, p. xv).

But perhaps, too, the experience of Greece and of the general social unrest across Europe and the United States in the wake of the global crash in 2008 points us back towards what one might describe as a more muscular form of domination, where the power of the state - albeit perhaps in defence of Empire rather than the mere nation-state itself - is exerting itself with less and less concern for hegemonic coaxing of a compliant population. As Pilger notes, "the widely held belief among anti-globalisation campaigners that the state has 'withered away' is misguided, along with the view that transnational corporate power has replaced the state and, by extension, imperialism. As the Russian dissident economist Boris Kagarlitsky points out, 'Globalisation does not mean the impotence of the state, but the rejection by the state of its social functions, in favour of repressive ones, and the ending of democratic freedoms'” (Pilger, 2002, p. 5).

As for Gill's sometimes rather bleak analysis of the chances for a more democratic world, for advocates of transnational democracy his (and others') analysis is not valid grounds for abandoning the project but on the contrary advocating it more vigorously. In keeping with the more Foucauldian understanding of knowledge/power, Hardt \& Negri see the apparatus of Empire also as the site of resistance to it, and the locus of potential for a more democratic world. They assert that the "creative forces of the multitude that sustain Empire are also capable of autonomously constructing a counter-Empire, an alternative political organisation of global flows and exchanges" - witness the 'Occupy' movement and how it spread across the world - "The struggles to contest and subvert Empire, as well as those to construct a real alternative, will thus take place on the imperial terrain itself - indeed, such new struggles have already begun to emerge [...] the multitude will have to 
invent new democrative forms and a new constituent power that will one day take us through and beyond Empire" (Hardt \& Negri, 2000, p. xv)

Moves towards transnational democracy in the 21st century (McGrew, 2002; Hardt \& Negri, 2000) are most likely to be mediated by information communication technologies, and facilitated by those ICTs which foster and encourage links between people across national boundaries - such as the global social-networking tools being discussed in this paper. The media through which such links are being made, however, are not only prey to, but in some cases the arms of forces quite antithetical to both national and transnational democracy. Despite the famous use of Facebook during the Arab Spring of 2011 in Tunisia and Egypt and elsewhere, Facebook presents a classic example of hegemonic transnational capitalism at work, as this paper now seeks to outline.

\section{Transnational Capital and Social Networking}

It is the contention of this paper that Social Networking Sites - and Facebook in particular -display precisely the Gramscian constellation of behaviours between a dominant bloc of venture capitalists who have achieved hegemony in the New World Order of Empire and the tens of millions of us who willingly surrender our personal data and the conduct of our friendships and (online) social ties to their marketplace - notwithstanding the use of such sites as tools for resistance, as evidenced by the Arab Spring. Interestingly, playing down the use of Facebook as a resistance tool, Mark Zuckerberg said at the Paris eG8 meeting in 2011, referring to the uprisings in Tunisia and Egypt:

My own opinion is that it would be extremely arrogant for any specific tech company to claim any meaningful role in those [...] I think that Facebook was neither necessary nor sufficient for any of those things to happen. I do think over time the internet is playing a role in making it so people can communicate more effectively and that probably does help to organise some of these things. If it weren't Facebook it would be something else (Bradshaw, 2011).

This is extremely clever expectation management, with an eye to the sensitivities of advertising executives wary of the products they represent being associated with socially disruptive media - or indeed anything unsavoury. Witness the rapid flight of advertisers from the News of the World once the Milley Dowler revelations broke, in the UK, in July 2011 (Sweeney, 2011). It is important to Zuckerberg's bottom-line, in his ad-supported business, that Facebook continues to be seen as safe, socially conservative, and a place for innocent friendship. This is as true with regard to political movements as it is with regard to the visibility of the advertising that supports the site. There is an understanding amongst marketing professionals, for example, that "the reason that people are attracted to social networks in the first place is that reliance on user-generated content is seen as relatively free of traditional corporate content and advertising" (Goad \& Mooney, 2008) Any advert, in other words, must fit the environment in which it is placed. Moreover "if users perceive that a social network is becoming 'polluted' they will leave $\downarrow$ and the evidence suggests that this can happen extremely quickly" (Goad \& Mooney, 2008). Indeed, there have been a number of developments during the very recent past that have begun to highlight a much more sinister underbelly to the social networking phenomenon.

The biggest players in the world of the internet retain the lustre of electronic frontier pioneers (see Turner, 2006) by the merest hair's breadth - and a good deal of marketing hype. Google, created by Larry Page and Sergey Brin as PhD students at Stanford, whose famous motto, "Don't be evil" and desire "to organize the world's information and make it universally accessible and useful," had one big idea - they saw Search as the most important thing on the web, and created an algorithm that credits a site that is linked to by other sites with a ranking that will enable it to come top of the search results. Their market capitalisation in $3^{\text {rd }}$ quarter 2011 was about $\$ 179 \mathrm{bn}$ (Indigo, 2011a). They are, of course, an ad-supported business. Amazon, founded by Jeff Bezos in 1994, is the largest online retailer in the US, and 3rd largest in UK. Its market capitalisation in $3^{\text {rd }}$ quarter 2011 was \$102bn (“Google and Facebook”, 2011; Indigo 2011b) - 2nd after Google. As the biggest online retailer it is famous for its much acclaimed internal advertising: 'people who bought $X$ also bought $\mathrm{Y}$.' 
But arguably the elite of $21^{\text {st }}$ century internet billionaires are Peter Thiel, Luke Nosek, Ken Howery and Max Levchin ("Peter Thiel," n.d.; "Max Levchin," n.d.). They formed Paypal in March 2000, which charges a fee for online financial transactions, and which they sold in October 2002 for $\$ 1.5 \mathrm{bn}$ to eBay, which was valued in $3^{\text {rd }}$ quarter 2011 at $\$ 43.3 \mathrm{bn}$ (Indigo, 2011c), fourth after Facebook. Facebook itself, valued by Goldman Sachs in Jan 2011 (Blackden, 2011), when it invested $\$ 450 \mathrm{~m}$ in the site, at $\$ 50 \mathrm{bn}$ (3rd after Amazon) - although famously, and publicly, the creation (if not the idea) of Mark Zuckerberg - is, of course, actually the shrewd business proposition of Peter Thiel, who used his money from the sale of Paypal to create a web 2.0 investment hedge fund called the Founders Fund, with Luke Nosek and Ken Howery, along with Sean Parker of Napster and Plaxo. Thiel was the first and main Venture Capitalist behind Facebook. He is reputed to own $5.2 \%$ which he bought in summer '04 for $\$ 0.5 \mathrm{bn}$ - now worth at least $\$ 2 \mathrm{bn}$ (Blackden, 2011; "Peter Thiel," n.d.). So successful has Peter Thiel become, he is now on the steering committee of the Bilderberg Group, arguably the single most obvious example of how Empire works (Bilderberg, 2011). Max Levchin, meanwhile, after Paypal, created Slide, which did media-sharing for MySpace and Facebook, and sold it in August 2010 for \$182m ("Max Levchin," n.d.). Levchin now works for Google. Even the employees who worked for Paypal back in the early days did rather well. Chad Hurley, Steve Chen, and Jawed Karim - all early Paypal employees - created Youtube in 2005, and in October 2006 sold it to Google for \$1.65bn ("Chad Hurley," n.d.).

This might on the face of it seem quite a similar story to that told by Fred Turner in his insightful tale of Stewart Brand, the Whole Earth Catalog, and the splicing of Republican entrepreneurialism, hippie communalism, and cold war collaboration in computing teams that produced a large number of 'internet entrepreneurs' through the 1960s, 70s, 80s and 90s (Turner, 2006). But for all that Peter Thiel and his companions - and Mark Zuckerberg too - might have been inspired by this legacy, by the time Zuckerberg was creating Facebook, Thiel was a multi-millionaire investor with ideas beyond simply making more money. "At PayPal, he and Levchin talked about their online payments system as creating a new world currency free from government control," but - of course - controlled by them and their investors, instead. "Armed with a definition of entrepreneur that includes but isn't limited to - making money, it becomes clearer why Thiel took a bet on Zuckerberg's then little-known start-up" (Blackden, 2011). The possibilities of global hegemony shone in this neoconservative entrepreneur's eyes. "Thiel is a member of TheVanguard.Org, an internet-based neoconservative pressure group that was set up to attack MoveOn.org, a liberal pressure group that works on the web. Thiel calls himself 'way libertarian'" (Hodgkinson, 2008).

For users of SNS such as Facebook, such sites must retain and foster the appearance of a divorce between the non-hierarchical, non-commercial socializations on the site and the global multibillion dollar business and commercial concerns - and elites - that run the site. Just a glance at these numbers is enough to evidence that SNS are clearly no longer hobby activities, but large commercial enterprises. And for these businesses, the users and communities on these sites are resources to be exploited.

Facebook, as a protected and bounded SNS, provides an excellent example of these tensions between the social aspects of the network (the public face of the SNS) and the venture capitalism that goes on behind-the-scenes. If the question for users is 'can I make friends through Facebook?' then the question for owners of and investors in such sites is, in the words of reporter Tom Hodgkinson (2008) in his coverage of this issue, "can you make money out of friendship?" Few if any of the media reports on the phenomenon of social networking look at this aspect of Facebook-asbusiness, preferring to focus on the front-end, social activities it supports. In contrast, Hodgkinson's report into the commercial foundations of Facebook is of particular interest, not only for its novelty, but also for what it suggests about Facebook and similar SNS when considered from a Gramscian perspective. In particular, he highlights three inter-related aspects of Facebook operations which engage with the issues raised earlier in this paper.

Firstly, Facebook utilizes transnational networks like the internet, which are architecturally structured to transcend and subvert geography, whilst at the same time emphasising locality and the institutional, political or economic context in which the user is physically situated. Facebook's own 
help pages construct a rhetoric of communities-of-interest within communities-of-place. From the perspective of socialization, this may seem little more than a gimmick or an artefact of Facebook's evolution. But considered from an economic perspective, communities-of-interest within communities-of-place can be called by another name: markets. As Hodgkinson notes, "We are seeing the commodification of human relationships, the extraction of capitalistic value from friendships" (Hodgkinson, 2008). Whether investors or advertisers wish to capture all Facebook users in a place (e.g.: Harvard), or of a type (e.g.: movie goers), or both (Harvard students who watch movies), this information is given freely and willingly by Facebook users. By adopting and repositioning themselves as 'social facilitators' rather than, say, market researchers, Facebook develops a hegemonic relationship with their users. It is only when Facebook over-assumes on the relationship, that users become fully aware of the situation and withdraw their consent. But when the illusion of divorce is maintained, the 'unwitting collusion' that Gramsci spoke of is perpetuated.

This tendency to freely give up information online without consulting privacy policies or other information management statements is an interesting phenomenon, and one that anecdotal evidence suggests recurs across SNS sites (not just on Facebook) (Turkle, 2010). Again, the rhetoric of Facebook's public statements jars with the actions of behind-the-scenes innovations. Facebook's help pages seem to imply that privacy begins and ends with social network privacy $\downarrow$ the front-end social exchange of information. On this important issue, this social focus continues as users follow link after link, and whereas the privacy statement on social exchange (what will be termed here 'front-end privacy' for simplicity's sake) is written in fairly plain, non-jargon language, the statement on the data Facebook-as-business collects ('back-end privacy') uses more opaque language, and shifts quickly from mentions of automatic information collection (though cookies and IP logging) back towards the social rhetoric of front-end privacy issues.

Whilst there are important privacy and data security issues here, in terms of issues of hegemony, this (unwitting?) surrender of personal information only fuels the collusion between the rulers and ruled which puts the lie to the narratives of SNS as a non-hierarchical space. By using this information to fund its 'ad-supported business,' SNS such as Facebook are, in a sense, appropriating social networking innovations, ideas, and creativity, and repackaging them for safe consumption within existing social hierarchies. Users may feel they are creating something new, vibrant, theirs, not 'polluted' by existing structures and institutions, but behind the scenes it is literally business as usual. Punk may have felt the same way before they saw their styles and tropes for sale on the high street.

If it can be accepted that these users can be traded, repackaged, and sold as commodities, then what of their social ties? When considered from the perspective of the hegemonic dominance of the commercial interests over the social, the social networks take on new importance. For users, their ties allow them to build social networks (both intimate and distant) but, as noted above, these groups can also be articulated as a market. The 'commodification of friendship' can occur between two friends, or two hundred. Spencer and Pahl (2006), concerned with social dynamics, argued against the 'friendliness' of online friends, but in economic terms the strength of the tie or the 'genuine-ness' of the friend makes no difference. What is of interest to them is the information exchanged between these ties, across these networks (and with little concern for privacy policies). As long as the illusion of distance between the social and the commercial is maintained and the network is not 'polluted,' then the behind-the-scenes operations of such SNS can maintain hegemony, (and may even, it could be argued, head towards some notion similar to supremacy).

What will be interesting to observe is whether privacy and network information will be made accessible or protected on an individual basis or whether the lower common denominator approach will rule. That is, will information privacy levels be set differently for each individual in an exchange, or will an individual who has otherwise 'opted-out' have their information made accessible through their interactions with another user whose data is being collected? When considering the network as a market, the individual as a commodity, it may not be outrageous to expect owners and site operators to spread their nets as wide as they can. 
Facebook is not isolated in considering the network as a marketable commodity. Facebook is often referred to using the metaphor of the walled garden, which highlights the fact that Facebook shies away from cross-platform compatibility. Apple, it is increasingly apparent, behave in a similar fashion. Despite the advertising approaches opening up 'gates in the wall' to selected commercial sites, Facebook has tended towards remaining self-contained and apart from other SNS.

To maintain their position of authority in the rapidly growing online environments, the dominant bloc (socio-economic powers, as represented by groups such as venture capitalists) needed to react to and even absorb some of the aspects of the once marginalized sub-cultures who developed the proto-virtual social networks which fed into more recent versions of SNS. As social networking becomes more mainstream, moving from hobbyist/subcultural BBS to multi-platform, multimedia SNS that attract the attentions of some of the largest software and internet corporations on the planet, Gramsci's notion of cultural hegemony becomes even more relevant. Cultural hegemony explains how even the most marginal of subcultures (who is unfamiliar with the stereotypical computer nerd, bathed in the light of a monitor as they sit alone in a dark basement?) can be absorbed into the dominant socio-economic model if there is profit in it for the ruling elites. In Jodi Dean's analysis, it forms part of an entire new kind of capitalism she terms 'communicative capitalism': "the materialisation of ideals of inclusion and participation in information, entertainment, and communication technologies in ways that capture resistance and intensify global capitalism" (Dean, 2009: p. 2). Like punk, sanitized and repackaged for the masses, social networking has been appropriated from the DIY, hacker, and geek subcultures, cleared of its need for coding ability or technological sophistication (measures by which, in part, these subcultures defined themselves) and resold. A recent survey suggests that the average social gamer, sitting at her computer connected to the internet, playing, among other games, Farmville, is a 43 year old woman (Robyn, 2010).

\section{Discussion and Conclusion}

Utopian rhetoric surrounding Web 2.0 social networking creates an image of a social space, mediated by transnational communication tools, that is democratic, anti-hierarchical, open, and unconcerned with excessive capitalist agendas (see, for example, the completely affirmative and uncritical account by Tapscott and Williams entitled, "Wikinomics" critically reviewed by Fuchs, 2008) Clearly, as this paper has also argued, this perspective ignores the hidden aspects of Social Networking Sites as corporate entities with obligations to venture capital investors and shareholders. This paper puts forward the position that, rather than separate from the capitalist institutions and histories within which the internet is embedded, the internet, including SNS, is in fact a continuation of these practices and ideologies.

In Gramscian terms, if today's superstructures serve global capitalist accumulation by an increasingly remote super-rich elite, Facebook - with its half billion users per day (Svetlik, 2011) arguably forms the medium by which these superstructures panoptically monitor, micro-manage, target and adjust the delicate equilbria they maintain with the productive structures of 'communicative capitalism' (Dean, 2009) and the teeming millions who willfully partake in what they believe is a 'new' economy. Facebook forms, in short, the major part of the aether of communicative capitalism's transnational historical bloc, the site where the intensive negotiations of hegemony take place. Mark Zuckerberg, Peter Thiel, and the hedge funds that together own Facebook, are striving to make Facebook the Internet's High Street, where all commercial, social, and public activity takes place. In many respects, they have already succeeded.

One line of critique followed by both Mark Andrejevic (2007; 2009; 2010) and Christian Fuchs (2010a; 2011) in recent years has been viewing the privacy debate around social networking from the perspective of ownership and control. Andrejevic posits the notion of the 'digital enclosure' of personal information. As he points out, "information capture is only part of the story. When we participate in the interactive digital economy we become lab rats, subject to large-scale, ongoing controlled experiments conducted by a new breed of market researchers" (Andrejevic, 2009, p. 47). This is, in short, where Facebook ultimately becomes a $\$ 150$ bn company (Blackden, 2011). The 
debates around privacy on Facebook in particular, as Fuchs points out, depend, of course, on who you are: "privacy for dominant groups, in regard to the ability of keeping wealth and power secret from the public, is seen as problematic, whereas privacy at the bottom of the power pyramid for consumers and normal citizens is seen as a protection from dominant interests" (Fuchs, 2011, p. 140). Certainly the information about ourselves and our lives that we give up in the great "recentralisation" (Andrejevic, 2007) which is taking place as data is moved from our own computers into the "cloud" is information that is being as intensively data-mined as our emails in Gmail (Vascellaro, 2010) and our locations by both Google and Apple (Angwin \& Valentino-Devries, 2011). This line of enquiry, indeed, shows clearly where the dominant groups gain their power over the rest of us: targeted advertising made possible through data-mining, on the one hand, and on the other the invisible panoptic surveillance that ensures we all behave in the world of ubiquitous computing.

In sum, having made the move from hobby activity to corporate entity, social networking in general has been appropriated to become part of a hegemonic transnational capitalist strategy for globalised and unregulated market dominance. As the internet moves further away from its hobbyist origins and deeper into the mainstream of activities in capitalist societies (putting to one side for the moment the question of the international digital divide), what does a Gramscian analysis suggest might be in store for future permutations of online social networks?

Certainly, the question of 'pollution' will retain some of its importance for end users. However, like punk before it, as online social networking is repackaged and further removed from its hackerhobbyist origins, it might be plausible to suggest that the taint of commercial influence will not so automatically lead to users deserting that service. As hegemonic groups further appropriate the codes and tropes of the users, the distinction between owners and users, rulers and ruled, will decrease. This in turn might result in users being more accepting of offline power dynamics being replicated in online spaces: thus, online social networks will shake off their ties to counter-cultural ideologies and instead begin to replicate and resemble existing offline power dynamics. In doing so, the distinction between online and offline engagement may subsequently recede. As the opportunity to make pocket-money through SNS becomes more and more open to small-to-medium enterprises (SMEs) and individuals (Goad \& Mooney, 2008), in similar fashion to the 1980s sale of council housing (which transformed the working classes into property-owning middle classes in the UK), the distinction becomes sufficiently blurred for the rulers to rule not only with the consent but with the explicit support of the ruled. Through this process, offline economic relations are replicated online.

More broadly, although the phenomenon of the 'Dark Net' (Biddle, England, Peinado, \& Willman, 2002 ) is likely to persist as a virtual underbelly correlating to its non-virtual cousin, the hackerhobbyist has, like the punk, been stripped of political significance and has already become a cultural figure of good repute. It is truly not that long ago that spending large amounts of time in front of a computer screen was regarded as the behaviour of a young adolescent male, devoid of social skills. Now, more and more of us will be attached to our screens much of the time, at work and at home - being 'social'. This activity is increasingly seen not only as socially acceptable and a 'cool' thing to do, but crucial to our economic well-being. Here, indeed, we see the Gramscian overtones in our willingness to sit tight at our keyboards and contribute to the new online economy, as we flock in our millions to populate these new online social 'worlds.'

Finally, maintaining hegemony requires continual shifting and repositioning of the strategies and tactics that maintain consent, and requires that new, oppositional or counter-cultural movements, and socially revolutionary sub-cultures, are not only absorbed by the mainstream, but if potentially truly profitable, become the mainstream, once they have been cleansed of their political dimensions, and can be harnessed to replicate existing power dynamics. It will be worth watching developments in North Africa very closely in this regard, in the coming years. Just as the hackerhobbyist of not so long ago has become the cool online social networker partaking in a new transnational economy, so too the Arab youth that used Facebook to organise revolution may soon be using it to promote their own business interests. 
The venture capitalists at the top of this pile are certainly not making these things happen, in a somewhat crude interpretation of Gramscian dominance, nor are they necessarily part of any imperialist plot from Gill's US-led transnational historical bloc. But those which are able to stay at the top in this rapidly developing arena - like Peter Thiel and his cohorts - are adept at manipulating the information revolution for their own ends, and represent the ruling class of Hardt \& Negri's decentred transnational Empire. We, in turn, are happily dazzled by the Spectacle (Debord, 1995; Hardt \& Negri, 2000) of SNS, and seem to be gladly logging on and buying into it.

\section{References}

Althusser, L. (1970). Ideology and Ideological State Apparatuses. Retrieved from http://www.marxists.org/ Anderson, B. (2006). Imagined Communities. London: Verso.

Andrejevic, M. (2007). Surveillance in the Digital Enclosure. The Communication Review, 10(4), 295-317.

Andrejevic, M. (2009). Privacy, Exploitation, and the Digital Enclosure. The Amsterdam Law Forum, 4(1), 47-61.

Andrejevic, M. (2010). Social Network Exploitation. In Z. Papacharissi (Ed.), A Networked Self: Identity, Community, and Culture on Social Network Sites (pp. 82-101). New York: Routledge.

Angwin, J., \& Valentino-Devries, J. (2011, May 22). Apple, Google Collect User Data. Wall Street Journal. Retrieved from http://online.wsj.com/

Biddle, P., England, P., Peinado, M., \& Willman, B. (2002). The Darknet and the Future of Content Distribution. Seattle: Microsoft

Bilderberg (2011). Membership. Retrieved from http://www.bilderbergmeetings.org/governance.html

Blackden, R. (2011, March 12). Facebook Investor and PayPal Co-Creator: Peter Thiel believes Mark Zuckerberg's site is worth \$150bn. The Daily Telegraph. Retrieved from http://www.telegraph.co.uk/

boyd, d. (2006). Identity Production in a Networked Culture: Why Youth Heart MySpace. In D. Buckingham (Ed.), Youth, Identity, and Digital Media (pp. 119-142). Cambridge: MIT Press.

boyd, d. \& Ellison, N. B. (2007). Social Network Sites: Definition, History, and Scholarship. Journal of Computer-Mediated Communication, 13(1), 210-230.

Bradshaw, T. (2011, May 26). 'Facebook's Arab Spring Role 'Overplayed', Says Zuckerberg. Financial Times. Retrieved from http://blogs.ft.com/

Chad Hurley. (n.d.). In Wikipedia. Retrieved from http://en.wikipedia.org/wiki/Chad Hurley

Chong, E., \& Xie, B. (2011). The Use of Theory in Social Studies of Web 2.0. In Proceedings of the 44th Annual Hawaii International Conference on System Sciences: Volume 03. HICSS. Washington, DC: IEEE Computer Society.

Dean, J. (2009). Democracy and Other Neoliberal Fantasies. Durham: Duke University Pess.

Debord, G. (1995). The Society of the Spectacle. New York, NY: Zone Books.

Facebook Scares Me. (2007 Aug 27). The Independent. Retrieved from http://www.independent.co.uk/

Feenberg, A., \& Bakardjieva, M. (2004). Virtual Community: No 'Killer Implication'. New Media and Society, 6(1), 37-43.

Foucault, M. (1994). The Subject and Power. In J. D. Faubian (Ed.), Essential Works of Foucault 1954-1984: Power. (pp. 326-348). London: Penguin Books

Fuchs, C. (2008). Review Essay of "Wikinomics: How Mass Collaboration Changes Everything" (Don Tapscott/Anthony D. Williams). International Journal of Communication, 2, 1-11.

Fuchs, C. (2010a). Labor in Informational Capitalism and on the Internet. The Information Society, 26(3), 179-196.

Fuchs, C. (2010b). Social Networking Sites and Complex Technology Assessment. International Journal of E-Politics, 1(3), 19-38.

Fuchs, C. (2010c). studiVZ: Social Networking in the Surveillance Society. Ethics and Information Technology, 12(2), 171185.

Fuchs, C. (2011). An Alternative View of Privacy on Facebook. Information, 2, 140-165.

Gill, S. (2003). Power and Resistance in the New World Order. Basingstoke: Palgrave.

Goad, R., \& Mooney, T. (2008). The Impact of Social Networking in the UK. London: Experian Integrated Marketing

Google and Facebook: The Key Facts. (2011, June 1). The Daily Telegraph Retrieved from http://www.telegraph.co.uk/

Gramsci, A. (2007). Selections from the Prison Notebooks. Kings Lynn, UK: MPG Books.

Halperin, R. (2006). Identity as an Emerging Field of Study. Retrieved from http://www.fidis.net/fileadmin/fidis/publications/2006/DuD09 2006 533.pdf

Hardt, M., \& Negri, A. (1994). Labor of Dionysus: A Critique of the State-form. Minnesota: University of Minnesota Press. Hardt, M., \& Negri, A. (2000). Empire. London: Harvard University Press. 
Hardy, M. (2002). Life Beyond The Screen: Embodiment and Identity Through the Internet. The Sociological Review, 50(4), 570-585

Hebdige, D. (1979). Subculture: The Meaning of Style. London: Routledge.

Hodkinson, T. (2008, Jan 14). With Friends Like These ... The Guardian. Retrieved from http://www.guardian.co.uk/

Indigo (2011a). Indigo Equity Research: Google Overview $3^{\text {rd }}$ Quarter 2011. Retrieved from http://www.indigo-equityresearch.com/sample/overview/Google Overview.pdf

Indigo (2011b). Indigo Equity Research: Amazon Overview $3^{\text {rd }}$ Quarter 2011. Retrieved from http://www.indigo-equityresearch.com/sample/overview/Amazon Overview.pdf

Indigo (2011b). Indigo Equity Research: eBay Overview $3^{\text {rd }}$ Quarter 2011. Retrieved from http://www.indigo-equityresearch.com/sample/overview/eBay Overview.pdf

Jones, S. (2006). Antonio Gramsci. London: Routledge.

Kirchhoff, L., Stanoevska-Slabeva, K., Nicolai, T. \& Fleck, M. (2008). Using Social Network Analysis to Enhance Information Retrieval Systems. World Wide Web Internet And Web Information Systems, 7, 1-21.

Liu, H, Maes, P., \& Davenport, G (2006). Unravelling the Taste Fabric of Social Networks. International Journal on Semantic Web and Information Systems, 2(1), 42-71.

Livingstone, S., \& Helsper, E. J. (2007). Taking Risks When Communicating on the Internet: The Role of Offline SocialPsychological Factors in Young People's Vulnerability to Online Risks. Information, Communication \& Society, 10(5), 619-644

Madden, M., \& Fox, S. (2006). Riding the Waves of 'Web 2.0'. Retrieved from http://www.pewinternet.org/PPF/r/189/report display.asp

Malone, J. (2010, December 15). The Rise of Facebook. The Daily Telegraph. Retrieved from http://www.telegraph.co.uk/

Max Levchin. (n.d.) In Wikipedia. Retrieved from http://en.wikipedia.org/wiki/Max Levchin

McGrew, T. (2002). Transnational Democracy: Theories and Prospects. In A. Carter \& G. Stokes (Eds.), Democratic Theory Today. (pp. 269-294). Cambridge: Polity.

Mesch, G. S., \& Talmud, I. (2007). Editorial Comment: e-Relationships: The Blurring and Reconfiguration of Offline and Online Social Boundaries. Information, Communication \& Society, 10(5), 585-589

Negri, A. (1992). Marx Beyond Marx: Lessons on the Grundrisse. London: Pluto Press.

Passavant, P., \& Dean, J. (2004). Empire's New Clothes: Reading Hardt and Negri. London: Routledge.

Peter Thiel. (n.d.) In Wikipedia. Retrieved from http://en.wikipedia.org/wiki/Peter Thiel

Pilger, J. (2002). The New Rulers of the World. London: Verso.

Plant, R. (2004). Online Communities. Technology in Society, 26(1) 51-65.

Richards, J. (2008, September 18). Fake Facebook Profile' Victim Awarded £22,000. The Times. Retrieved from http://technology.timesonline.co.uk/

Robins, K., \& Webster, F. (1999). Times of the Technoculture. London: Routledge

Robyn (2010). 2010 Social Gaming Research. Retrieved from http://www.infosolutionsgroup.com/2010 PopCap Social Gaming Research Results.pdf

Scholz, T. (2008). Market Ideology and the Myths of Web 2.0. First Monday 13(3). Retrieved from http://firstmonday.org/htbin/cgiwrap/bin/ojs/index.php/fm/article/viewArticle/2138/1945

Schonfeld, E. (2007, November 6). Liveblogging Facebook Advertising Announcement (Social Ads + Beacon + Insights). Techcrunch. Retrieved from http://www.techcrunch.com/

Searle, W., \& Ward, C. (1990). The Prediction of Psychological and Sociocultural Adjustment During Cross-Cultural Transitions. International Journal of Intercultural Relations, 14, 449-464.

Song, F.W. (2010). Theorizing Web 2.0. Information, Communication \& Society, 13(2), 249-275.

Spencer, L., \& Pahl, R. (2006). Rethinking Friendship: Hidden Solidarities Today. Princeton: Princeton University Press.

Svetlik, J. (2011, September 23). Facebook Attracts Half a Billion People in One Day. CNET. Retrieved from http://crave.cnet.co.uk/software/facebook-attracts-half-a-billion-people-in-one-day-50005304/

Sweeney, M. (2011, July 6). Procter \& Gamble, Asda and Tesco Consider Pulling News of the World Ads. The Guardian. Retrieved from http://www.guardian.co.uk/

Tom Tong, S., Van Der Heide, B., Langwell, L., \& Walther, Joseph. B. (2008). Too Much of a Good Thing? The Relationship Between Number of Friends and Interpersonal Impressions on Facebook. Journal of Computer-Mediated Communication, 13(3), 531-549.

Turkle, S. (1995). Life on the Screen: Identity in the Age of the Internet. London: Simon and Schuster.

Turkle, S. (2010). Alone Together. London: Basic Books.

Turner, F. (2006). From Counterculture to Cyberculture: Stewart Brand, the Whole Earth Network, and the Rise of Digital Utopianism. Chicago, London: University of Chicago Press.

Vascellaro, J. (2010, August 10). Google Agonizes on Privacy as Ad World Vaults Ahead. Wall Street Journal, Retrieved from http://online.wsj.com/ 
Walther, J. B., Van Der Heide, B., Kim, S.-Y., Westerman, D., \& Tong, S. T. (2008). The Role of Friends' Appearance and Behavior on Evaluations of Individuals on Facebook: Are We Known By the Company We Keep? Human Communication Research, 34(1), 28-49.

Wareham, J., Busquets, X., \& Austin, R. (2009). Creative, Convergent, and Social: Prospects for Mobile Computing. Journal of Information Technology, 24(1), 139-143.

\section{About the Author}

David Kreps

Dr David Kreps is Director of the Information Systems, Organisations and Society (ISOS) Research Centre at University of Salford and Vice Chair of the IFIP Working Group 9.5 on Virtuality, Social and Digital Media. He has published widely in Information Systems journals and conferences on eAccessibility and Virtuality. His background in Cultural Studies and Sociology foster a critical approach to his research in IS. David lectures in Web Development, Emerging Technologies, and Media Asset Management at the University of Salford. 